\title{
Multiletramentos e o feminino em memes de alunos do ensino médio do Instituto Federal de Mato Grosso do Sul
}

\author{
Fabiana Poças Biondo Araújo' (D) \\ Juvenal Brito Cezarino Júnior" (DD
}

RESUMO

O trabalho apresenta resultados de uma proposta de ensino realizada no Instituto Federal de Educação, Ciência e Tecnologia de Mato Grosso do Sul, campus Aquidauana, na perspectiva da pedagogia dos multiletramentos. Objetivou analisar, em memes produzidos por estudantes dos cursos de Edificações e de Informática, o processo de (res)significação do feminino antes e depois da proposta de ensino, por meio de abordagem interpretativista de pesquisa. De modo transdisciplinar, o artigo ampara-se em estudos sobre multiletramentos, meme, gênero e feminismo e mostra que a construção de sentidos sobre o feminino se dá pelo questionamento da norma hegemônica de gênero, em seus desdobramentos para a política de vigilância do corpo e do comportamento das mulheres. Isso ocorre antes e depois da proposta de intervenção, no entanto alguns casos são qualitativamente significativos quanto às mudanças na construção do feminino após a intervenção, na direção de maior empatia em relação ao sofrimento humano.

\section{PALAVRAS-CHAVE}

multiletramentos; meme; gênero; feminino; ensino médio.

'Universidade Federal de Mato Grosso do Sul, Campo Grande, MS, Brasil.

"Instituto Federal de Educação, Ciência e Tecnologia de Mato Grosso do Sul, Aquidauana, MS, Brasil. 


\title{
MULTILITERACIES AND FEMININE IN MEMES BY HIGH SCHOOL STUDENTS OF THE FEDERAL INSTITUTE OF MATO GROSSO DO SUL
}

\begin{abstract}
This work presents results of a teaching proposal made at the Federal Institute of Education, Science and Technology of Mato Grosso do Sul, Aquidauana campus, under the perspective of pedagogy of multiliteracies. Its purpose is to analyze the process of (re)signification of the feminine before and after the teaching proposal, through an interpretative research approach, in memes produced by students of the technical course of Buildings and Informatics. In a transdisciplinary perspective, it is based on studies on multiliteracies, meme, gender and feminism and shows that the construction of meanings on the feminine is due to the questioning of the hegemonic norm of gender, in its unfolding for the policy of surveillance of the body and behavior of women. This occurs before and after the proposed intervention; however, some cases are qualitatively significant as to the changes in the construction of the female after the intervention, towards a greater empathy for human suffering.
\end{abstract}

\section{KEYWORDS}

multiliteracies; meme; gender; feminine; high school.

\section{MULTILETRAMENTOS Y EL FEMENINO EN MEMES DE ALUMNOS DE LA SECUNDARIA DEL INSTITUTO DE MATO GROSSO DO SUL}

\section{RESUMEN}

El trabajo presenta los resultados de una propuesta de enseñanza realizada en el Instituto Federal de Educación, Ciencia y Tecnología de Mato Grosso do Sul, campus Aquidauana, bajo la perspectiva de la pedagogía de los multiletramentos. El objetivo fue analizar, en memes producidos por estudiantes de los cursos de Edificaciones y de Informática, el proceso de (re)significación del femenino antes y después de la propuesta de enseñanza, por medio de un abordaje interpretativista de investigación. En una perspectiva transdisciplinaria, se ampara en estudios sobre multiletramentos, meme, género y feminismo y muestra que la construcción de sentidos sobre lo femenino se da por el cuestionamiento de la norma hegemónica de género, en sus desdoblamientos para la política de vigilancia del cuerpo y del comportamiento de las mujeres. Esto ocurre antes y después de la propuesta de intervención; sin embargo, algunos casos son cualitativamente significativos en cuanto a los cambios en la construcción del femenino después de la intervención, hacia una mayor empatía hacia el sufrimiento humano.

PALABRAS CLAVE

multiletramentos; meme; género; femenino; escuela secundaria. 


\section{INTRODUÇÃO}

Este trabalho apresenta alguns resultados de pesquisa sobre o processo de significação do feminino construído via memes por estudantes do ensino médio técnico do Instituto Federal de Educação, Ciência e Tecnologia de Mato Grosso do Sul (IFMS), campus Aquidauana. Com base em motivações pessoais aliadas à carência de discussões dessa natureza na instituição educacional de formação tecnológica, realizamos um estudo com estudantes de dois cursos técnicos integrados ao ensino médio, Edificações e Informática, com os intuitos iniciais de ampliar e construir conhecimentos com esses estudantes a respeito de questões de gênero e feminismo, em uma perspectiva de trabalho fundamentada na pedagogia dos multiletramentos (NLG, 2006).

Dois fatos, sobretudo, impulsionaram tanto a realização do projeto de ensino quanto a discussão que propomos aqui. $\mathrm{O}$ primeiro deles foi, no dia 3 de fevereiro de 2015, a inauguração na capital sul-mato-grossense, Campo Grande, pela então presidenta Dilma Rousseff, da primeira Casa da Mulher Brasileira, um meio de garantir o atendimento às vítimas de violência. Segundo o Balanço Anual de 2014 da Secretaria Nacional de Políticas para as Mulheres (Brasil, 2014), Campo Grande foi a capital com a maior taxa de atendimentos registrada no serviço; em 2016, ocupou o segundo lugar, ficando atrás apenas de Brasília. Somamos a isso o segundo fato. Diagnosticamos que em Aquidauana, município situado a $139 \mathrm{~km}$ da capital de Mato Grosso do Sul, são notórios os registros de violência contra a mulher, o que impulsionou o Executivo da cidade, em 7 de novembro de 2017, a sancionar a Lei no $2.540 / 2017$, que instituiu a Semana Municipal de Combate à Violência Doméstica e Familiar contra a Mulher.

A nosso ver, a implantação da lei e a criação da Casa da Mulher corroboram a necessidade de se pensar em ações que possam de alguma forma diminuir índices de violência no estado. A escola, como instituição social e uma das formadoras da pessoa humana, tem o compromisso de promover discussões que permitam a melhor conscientização do lugar social historicamente delineado à mulher, de modo a evidenciar a "violência e o sofrimento humano como constitutivos de formações culturais hegemônicas e binarizantes de gênero e de sexualidade" (Biondo, 2015, p. 211).

Conforme Miskolci (2017, p. 42), "é no ambiente escolar que os ideais coletivos sobre como deveríamos ser começam a aparecer como demandas e até mesmo como imposições, muitas vezes de uma forma violenta". Tais construtos são culturais - evidentemente também políticos - e visam adequar os sujeitos a uma norma hegemônica de gênero, podendo levar à marginalização os que resistirem a ela. Além disso, por meio de atividades de leitura, de compreensão e de produção oral e escrita, a sala de aula de línguas é um lugar propício à construção de significados e à reflexão sobre como agir no mundo social (Moita Lopes, 2002).

Trabalhamos na aula de língua portuguesa, com as turmas do IFMS mencionadas, a leitura, a reflexão e a produção de textos diversos e multimodais, de forma a desenvolver tanto a consciência crítica sobre aspectos culturais, formações hegemônicas e subversivas de construção do gênero quanto a significação por intermédio de linguagens outras que não apenas a escrita — duas arestas educa- 
cionais implicadas na pedagogia dos multiletramentos (NLG, 2006). Diante de todo o material produzido pelos estudantes e registrado pelo professor responsável, apresentamos uma discussão sobre as significações do feminino em memes criados pelos alunos e discutidos em uma página da rede social Facebook construída para o estudo. Duas questões basilares guiaram-nos nessa proposta: como se dá o processo de (res)significação do feminino nos memes produzidos pelos alunos? Os memes revelam alguma mudança em relação aos significados do feminino em comparação à compreensão desses/as alunos/as antes do projeto de ensino realizado ${ }^{1}$ ?

Convém mencionar ainda que essa iniciativa se pretende alinhada às propostas do IFMS, uma vez que em seu projeto político de curso estão contempladas "iniciativas visando à qualificação profissional, ao desenvolvimento comunitário, à formação política e às inúmeras questões culturais pautadas em outros espaços que não o escolar" (IFMS, 2017, p. 8-9).

\section{MULTILETRAMENTOS E O MEME}

A pedagogia dos multiletramentos foi implementada por um grupo de estudiosos que ficou conhecido como o New London Group (NLG), no ano de 1996, tendo em vista a expansão do uso das tecnologias digitais na sociedade e a ampliação da pedagogia do letramento, de modo a concatenar as relações entre múltiplas culturas e a diversidade de textos em circulação nas práticas sociais. Segundo tais pesquisadores, a pedagogia do letramento deveria, a partir de então,

explicar a crescente variedade de formas de texto associadas às tecnologias de informação e multimídia. Isto inclui compreensão e domínio competente de formas de representação que estão se tornando cada vez mais significativas no ambiente global de comunicação, tais como imagens visuais e sua relação com a palavra escrita. (NLG, 2006, p. 61, tradução nossa)

Ao chamar a atenção para as multissemioses textuais implicadas na produção de sentidos, o NLG aponta para as relações de semelhança, distanciamento ou complementaridade de outras linguagens (imagem, cor, som) com a escrita, abrindo o campo para um repensar as práticas grafocêntricas tradicionais nas instituições e/ ou situações de ensino-aprendizagem formais. A complementaridade de linguagens é fundamental nas práticas letradas contemporâneas, que precisam ser apreendidas em sua diversidade, "numa perspectiva mais ampla que a do letramento grafocêntrico convencional com seus padrões textuais e gráfico-visuais próprios da mídia impressa" (Signorini, 2012, p. 284).

Para Knobel e Lankshear (2006), é preciso encarar a leitura e a escrita, nesse paradigma, como formas de dar sentido à nossa experiência, deslocar o processo de compreensão para universos culturais particulares e entender que variados tipos de

1 Para propor respostas à segunda questão, valemo-nos também de um questionário realizado com os estudantes em momento anterior à execução do projeto. Tal questionário orienta, assim como os memes, algumas análises do estudo. 
texto requerem também “backgrounds e habilidades um pouco diferentes”(Knobel e Lankshear, 2006, p. 2). Supõe-se, portanto, uma expansão das habilidades de escrita e leitura, pressuposta na imersão em práticas múltiplas quanto à cultura e, em geral, baseada na hipermídia.

Os autores destacam que muitas das mudanças nos processos de leitura e escrita na atualidade estão ligadas à expansão e ampliação do uso das tecnologias digitais, de rede. Tal uso demanda que sejam feitas coisas novas, acompanhando as contínuas mudanças relacionadas às redes e tecnologias digitais e atentando para o contexto social, cultural e político, que exerce grande influência na prática de leitura e escrita. É preciso, assim, que a escola promova competências para lidar com uma abordagem de uso da língua atenta às multiplicidades culturais e às multissemioses textuais, especialmente as ampliadas em razão da hipermídia (Knobel e Lankshear, 2006; NLG, 2006).

Entre os textos multimodais em circulação no mundo digital, o meme, objeto de análise deste trabalho, tem a base de seu termo constituída há muitos anos, como uma aférese de mimeme, tal como proposto pelo biólogo Dawkins (2017). Mimeme, de etimologia grega, tem a mesma raiz de mimese e significa imitação. O fonema inicial foi suprimido intencionalmente, pois Dawkins (2017) buscava um nome simples cuja sequência fônica parecesse gene, resultando em meme. Adotando a perspectiva darwiniana, o autor afirma, analogamente, que, assim como os genes replicam por intermédio do processo de duplicação de uma molécula de DNA de dupla cadeia, o meme é responsável pela replicação cultural, a qual acontece por meio da atividade social de transmitir informação. Em sua ótica, a replicação ocorre por fatores genéticos e culturais, sendo estes últimos compreendidos como comportamentos, hábitos, ideologias e valores espalhados mediante a imitação ou cópia.

Ao tratar desse gênero digital no campo da linguagem, Recuero (2018, p. 124) explica que "a propagação do meme é cíclica e nem sempre implica a reprodução fiel da ideia original. Ao contrário, as mudanças e transformações são frequentes e comparadas, em sua abordagem, às mutações genéticas: essenciais para a sobrevivência do meme". A autora afirma também que os memes são propagados com base na percepção do ganho social que a pessoa que o divulgou obtém. À essa motivação, a pesquisadora dá o nome de capital social, ou seja, é o que impulsiona alguém a propagar o meme: reputação, visibilidade, popularidade etc.

Quanto à sua composição, conforme Inocêncio (2016, p. 10), os memes são construídos por meio de repetições de um modelo primário, que pode se transformar de diversas maneiras, pela intertextualidade e via retextualizações que costumam se distanciar da versão original, embora esta possa ser identificada. Para a autora, os memes são uma forma de se expressar e de participar socialmente e capazes de ampliar debates e ações políticas de sujeitos em suas interações na internet, possibilitando outros modos de ser e estar na rede.

Milner (2012, p. 48), por sua vez, lembra que os memes funcionam quase que inteiramente como uma piada, com o diferencial de que alguns deles exigem reflexão sobre questões políticas e, tais quais outros textos de cultura popular, podem atuar como "uma poderosa sátira política" (Milner, 2012, p. 48). Para o autor, os memes ainda costumam ser utilizados como representação de discursos e identidade, de modo a reforçar, mais uma vez, seu caráter político. Sendo assim, refletir sobre 
como os memes são feitos pode revelar aspectos da participação social dos sujeitos, uma vez que, por meio dos elementos formais de um texto, se revelam escolhas individuais entrelaçadas a conexões culturais.

Por se tratar de um texto multissemiótico, sabemos ainda que, na produção de um meme, há todo um trabalho de relacionar linguagem verbal e linguagem imagética, de modo que, juntas, elas produzam um efeito de sentido imbuído de crítica social. Portanto, no processo de criação de um meme, ainda que não tenham consciência disso, os estudantes elegem a imagem que melhor se coaduna à crítica exposta na linguagem verbal, e vice-versa, fazendo com que as múltiplas semioses operem juntas na produção de sentidos. Nessa perspectiva, Kress e Van Leeuwen (2006) pontuam que, ao produzir signos, as pessoas fazem escolhas formais de maneira a se alinhar aos significados que elas pretendem expressar, em qualquer meio no qual estejam imbuídas.

No intuito de encurtar a distância entre práticas pedagógicas e mundo social, elegemos o meme para o estudo por ser ele parte das relações diárias dos estudantes com a linguagem, com o propósito de engajar os alunos nas práticas discursivas da sala de aula. Ao propormos a construção desse gênero, cuja circulação se dá quase que tão somente por meio das redes sociais, corroboramos a proposta de Rojo (2009, p. 12) de que é tarefa também da escola "potencializar o diálogo multicultural, trazendo para dentro de seus muros não somente a cultura valorizada, dominante, canônica, mas também as culturas locais e populares e a cultura de massa para torná-las vozes de um diálogo, objetos de estudo e de crítica".

Compreendemos, ainda, com base em Barton e Lee (2015, p. 48), que o produtor de um texto de circulação online, tal como o meme, é um "designer", pois cabe a ele escolher entre opções de leiaute, imagens e outras linguagens disponíveis, o que sublinha sobretudo a noção de inexistência de neutralidade na tessitura textual. Na esteira de Fabrício (2006, p. 48), assumimos que "nossas práticas discursivas não são neutras, e envolvem escolhas (intencionais ou não) ideológicas e políticas, atravessadas por relações de poder, que provocam diferentes efeitos no mundo social".

O trabalho com memes pode, então, "incorporar o melhor da mídia participativa: participação democrática, diálogo diverso e debate relevante”(Milner, 2012, p. 22, tradução nossa), além da possibilidade de contestar discursos naturalizados, oportunizando questionamentos e ressignificações. Nesse sentido, produzir esse gênero textual pode ser uma prática importante de aprendizagem, uma forma de participar e agir na vida social envolvendo-se em interações em redes sociais, no contexto da rápida expansão do acesso à internet (Knobel e Lankshear, 2006).

Tendo em vista essas possibilidades, apostamos na produção de memes como forma de expor e questionar lugares sociais e comportamentos tradicionalmente reservados ao ser mulher. Dedicamo-nos a esse tema na seção a seguir.

\section{O GÊNERO E O FEMININO}

Os estudos de gênero, embora estejam longe de se organizarem como um campo totalmente homogêneo, costumam partir de um lugar-comum: o questionamento da subordinação histórica da mulher em relação ao homem. Para Matos (2008), todas 
as áreas interessadas em discutir questões de gênero deveriam partir desse ponto para compreender e lançar explicações sobre as diversas faces de dominância e opressão que envolvem as relações de gênero. Desse lugar-comum, movimentos sociais e epistemologias construíram-se em torno do sujeito mulher, inicialmente, e da ideia de gênero, a partir de meados dos anos de 1970 e fortemente na década de 1980 .

Ao questionar a subordinação histórica do feminino, Saffioti (1987, p. 11) salienta que se trata de um processo naturalizado em nossa cultura, assim como a discriminação de outras categorias sociais, e alerta para o fato de ser a naturalização “o caminho mais fácil e curto para legitimar a superioridade dos homens" (Saffioti, 1987, p. 11) — brancos, heterossexuais, classe média, cristãos —, considerados em sua referência humanista. A autora compreende por naturalização o fato de determinado construto social parecer inquestionável, como se fosse dado pela natureza. É também nessa direção que Louro (2003) destaca o modo como a sociedade classifica e rotula os sujeitos, dividindo-os entre polos opostos de categorias e fixando suas identidades. Para a autora, "ela define, separa e, de formas sutis e violentas, também distingue e discrimina" (Louro, 2003, p. 16).

De maneira a desestabilizar essa naturalização, estudos de gênero desenvolvidos na esteira da pós-modernidade e do pós-humanismo questionam fortemente as normas de gênero instituídas na sociedade. Informados pelo pensamento pós-estruturalista que se alastrou na França na década de 1980, sobretudo pelas ideias de Michel Foucault e Jacques Derrida (Narvaz e Koller, 2006), estudos sobre a performatividade do gênero e as teorias queer (Nelson, 2006; Louro, 2008; Butler, 2017), por exemplo, afirmam a necessidade de compreender as categorias e os estereótipos do gênero como construções sociais que se dão na interação, na linguagem.

Para Butler (2003, 2018), a performatividade do gênero tem a ver com o poder da linguagem de promover ações no mundo social. Logo, performar o gênero equivale a uma ação, a um modo de fazer o gênero existir ou acontecer. Assim sendo, é possível subverter a norma de gênero instituída pela cultura ocidental, ampliando as possibilidades de existência das identidades de gênero. Segundo essa norma, existiriam comportamentos sociais e sexuais fixamente estabilizados para um e outro lado do binário homem/mulher.

A pesquisadora sugere, então, a desconstrução do "binarismo de gênero" com vistas a desnaturalizá-lo, uma vez que, segundo ela, o ato de classificar pessoas como dos gêneros feminino e masculino com base em seu sexo biológico impõe aos seres humanos comportamentos e expectativas sociais, impedindo-os de se constituírem em sua individualidade. Nessa visão, as pessoas que não correspondem a essas "expectativas sociais" são postas à margem. Portanto, a filósofa alega que as práticas de linguagem exercem papel fundamental no processo de significação do gênero na cultura, pois elas são construídas segundo relações de poder que podem prescrever discursos de invisibilidade para a categoria de mulher, por exemplo. De acordo com Butler (2003, p. 161), “a nomeação é, ao mesmo tempo, o estabelecimento de uma fronteira e também a inculcação repetida de uma norma”.

Nesse mesmo viés, Goellner (2003, p. 29) afirma que "a linguagem não apenas reflete o que existe. Ela própria cria o existente e, com relação ao corpo, a linguagem tem o poder de nomeá-lo, classificá-lo, definir-lhe normalidades e anormalidades". 
Isto posto, entendida a linguagem de modo amplo, na esteira das teorias dos multiletramentos que informam este trabalho, também a imagem é uma maneira de (res)significar o gênero em nossa sociedade. Assim, conforme Sabat (2003, p. 150), "a construção de imagens que valorizam determinado tipo de comportamento, de estilo de vida ou de pessoa, é uma forma de regulação social que reproduz padrões mais comumente aceitos em uma sociedade”. A partir do momento em que há a conscientização sobre essas formas de controle, é possível firmar um posicionamento de resistência e de questionamento da ordem hegemônica de gênero.

Convém ressaltar que, no contexto de interação, quando percebem o discurso como construção social, os sujeitos podem se ver como verdadeiros atores na construção de significados no mundo social, o que inclui "a possibilidade de permitir posições de resistência em relação a discursos hegemônicos, isto é, o poder não é tomado como monolítico e as identidades sociais não são fixas" (Moita Lopes, 2002, p. 55).

Nessa perspectiva, compreendemos a real necessidade de a escola se incumbir de discutir normas opressoras de gênero em sua relação com o sujeito do feminino e, também, de se firmar como resistência às construções sociodiscursivas que atuam na configuração da opressão, de modo a diminuir as desigualdades e, por consequência, o sofrimento humano. Por esse viés, fundamentados em Hooks (2018), acreditamos que, "se não trabalharmos para criar um movimento de massa que oferece educação feminista para todo mundo, mulheres e homens, teoria e prática feministas serão sempre enfraquecidas pela informação negativa produzida na maioria das mídias convencionais" (Hooks, 2018, p. 47-48).

\section{METODOLOGIA DA PESQUISA}

Esta pesquisa situa-se no campo aplicado dos estudos da linguagem e, dessa forma, torna-se importante a compreensão de que seu viés teórico-metodológico é de natureza complexa, pois movimenta um conjunto variado de teorias que assinala seu caráter multidisciplinar. Analisar o objeto segundo uma perspectiva que envolve vários campos do conhecimento, conforme aponta Kleiman (1998, p. 66), "é identificar os grandes problemas sociais que interessam a mais de uma área e cujo estudo precise dos esforços de diversas subdisciplinas da Linguística Aplicada”. Também, Rajagopalan (2003) destaca a importância da interação com outras vertentes do saber, pois, para ele, "os grandes momentos na história da linguística invariavelmente foram aqueles nos quais houve intensos diálogos inter- e transdisciplinares em torno de questões mais amplas envolvendo a linguagem” (Rajagopalan, 2003, p. 40-41).

Além disso, a pesquisa possui cunho interpretativo e qualitativo, porque os dados gerados e coletados foram analisados mediante a progressão das etapas propostas, nas quais nos envolvemos como professores e como pesquisadores. Por esse motivo, trata-se ainda de pesquisa de cunho etnográfico, levando-se em conta a imersão de um dos pesquisadores diariamente no campo da pesquisa e o processo de envolvimento deliberado nas análises dos dados coletados. Essa é uma característica importante das pesquisas em linguística aplicada, nas quais há preocupação com a caracterização dos participantes, e do "contexto — situacional, institucional e microssocial em que eles atuam” (Kleiman, 1998, p. 61). 
Dada a importância da triangulação de mais de um tipo de registro a se configurar como dado em pesquisas qualitativas, este estudo teve seu corpus de análise construído pela produção e coleta dos seguintes registros: questionários online, gravações em áudio das aulas, anotações em diário de campo, interação e realização das atividades em página criada no Facebook. Esses registros desenvolveram-se por meio de um projeto de ensino conduzido no ensino médio técnico do IFMS, campus Aquidauana, conforme mencionamos anteriormente.

O projeto de ensino ocorreu de 22 de maio a 12 de junho de 2018 , com o intuito de promover o engajamento crítico dos estudantes dessa escola técnica, bem como viabilizar a leitura e a produção de textos multimodais ao encontro da pedagogia dos multiletramentos. Envolveu o total de 58 estudantes do $5^{\circ}$ semestre de dois cursos técnicos integrados ao ensino médio, Edificações e Informática, compostos de 26 e 32 estudantes, respectivamente.

O primeiro passo consistiu na aplicação de um questionário de 20 perguntas (três dissertativas e 17 de assinalar), organizado pelo professor no Google Formulários. Respondidas as questões, o próprio sistema estruturou as respostas, gerando gráficos para perguntas de assinalar, auxiliando na organização e análise dos dados. A pergunta-chave, que, além de nos proporcionar um diagnóstico sobre o que os respondentes compreendiam da questão, nos permitiu planejar as etapas vindouras, foi: o que é feminismo? Além dessa questão, foram feitas outras que versavam acerca da compreensão dos conceitos de feminismo, gênero e machismo, além de outras concernentes a comportamentos sociais tradicionalmente femininos.

Reunidas as respostas, realizamos a primeira análise das informações geradas, que nos permitiram pensar sobre quais atividades poderiam ser propostas para a intervenção/o projeto de ensino - entendido aqui como período de reflexão, debates, leitura e produção de textos referentes à temática abordada. No intuito de ilustrar as primeiras considerações dos estudantes a respeito da questão, apresentamos no Quadro 1 um recorte ipsis litteris de seis respostas que consideramos representativas das demais que se seguiram à pergunta-chave sobre o que é feminismo.

\section{Quadro 1 - Respostas de estudantes do Instituto Federal de Educação, Ciência e Tecnologia de Mato Grosso do Sul para o que é feminismo}

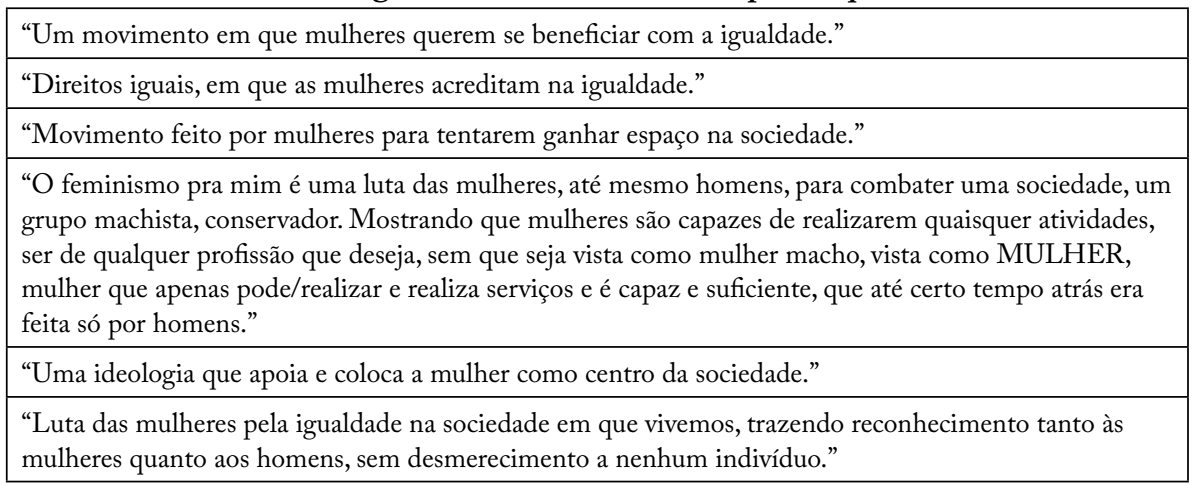

Fonte: arquivo pessoal dos autores (2018). 
Diante de tais respostas, observamos que havia entre os/as estudantes participantes da pesquisa quem pensasse que o feminismo é um movimento que circunscreve apenas mulheres, ou que seus objetivos seriam a inversão de poder entre homens e mulheres. De forma a promover o questionamento e a ampliar visões a respeito do tema abordado, ressignificando noções do senso comum, seguimos a acepção de que "o feminismo é essencialmente plural, um projeto filosófico de transformação social e política na contramão das opressões de sexualidade, gênero, raça, crença e classe social” (Pinto, 2018, p. 11). Guiados por essa compreensão, propusemos quatro encontros de intervenção, os quais tiveram as aulas gravadas e alguns pontos registrados em diário de campo. Quanto às atividades, optamos por trabalhar com gêneros textuais diversos (tirinhas, artigo de opinião, música e videoclipe, reportagem e memes), de modo a discutir como a figura feminina era construída nesses textos.

\section{O PROJETO DE ENSINO EM QUE FORAM GERADOS OS DADOS}

Ao abordar as temáticas identidade de gênero e feminismo em sala, buscamos promover meios e discussões que permitissem aos estudantes contestar, (re)elaborar e (des)construir discursos.

Desse modo, iniciamos o primeiro encontro com a música "Desconstruindo a Amélia”, da cantora Pitty², explorando letra e áudio. Além do título sugestivo, dada toda a carga semântica atribuída a Amélia — sinônimo de dona de casa —, a canção traz em sua narrativa o estereótipo da mulher na cultura do patriarcado, mas que em dado momento não mais aceita a condição em que está e resolve mudar o desfecho de sua história. A letra da referida música revela alguns construtos sociais naturalizados como próprios e exclusivos do universo feminino, principalmente no que se refere a serviços domésticos ("O ensejo a fez tão prendada/ Ela foi educada pra cuidar e servir [...] Disfarça e segue em frente/ Todo dia até cansar"), mas que são questionados ("Vira a mesa, assume o jogo/ Faz questão de se cuidar/ Nem serva, nem objeto/ Já não quer ser o outro/ Hoje ela é um também”), de maneira a evidenciar as subversões em relação aos comportamentos culturalmente atrelados aos sujeitos de sexo feminino.

Cabe salientar que elegemos essa música tendo em vista sua popularidade entre os alunos no contexto da pesquisa. Ademais, Pitty é uma cantora brasileira que tem ganhado paulatinamente os holofotes em discussões de gênero, pois muitas de suas canções são atravessadas por um teor crítico no que tange a discursos opressores culturalmente naturalizados.

Em um segundo momento, apresentamos algumas tirinhas de Mafalda, do cartunista argentino Joaquín Salvador Lavado Tejón, o Quino. Como atividade de contextualização, expusemos a nacionalidade do produtor das tirinhas, de modo a, além de situar o espaço delegado ao feminino em outro país, suscitar questionamentos sobre possíveis semelhanças (ou diferenças)

2 Disponível em: https://www.letras.mus.br/pitty/1524312/. Acesso em: 13 maio 2018. 
com a realidade cultural brasileira. Considerada por muitos como transgressora, Mafalda, representada por uma criança, é uma personagem que costuma trazer muitas reflexões acerca das normas regulatórias que definem o que é apropriado ao feminino. Não raro, tece críticas à maneira como sua mãe e sua amiga Susanita reforçam representações normativas de dominação patriarcal. A Figura 1 traz uma das tirinhas de Mafalda $^{3}$ que utilizamos em nosso projeto de intervenção:

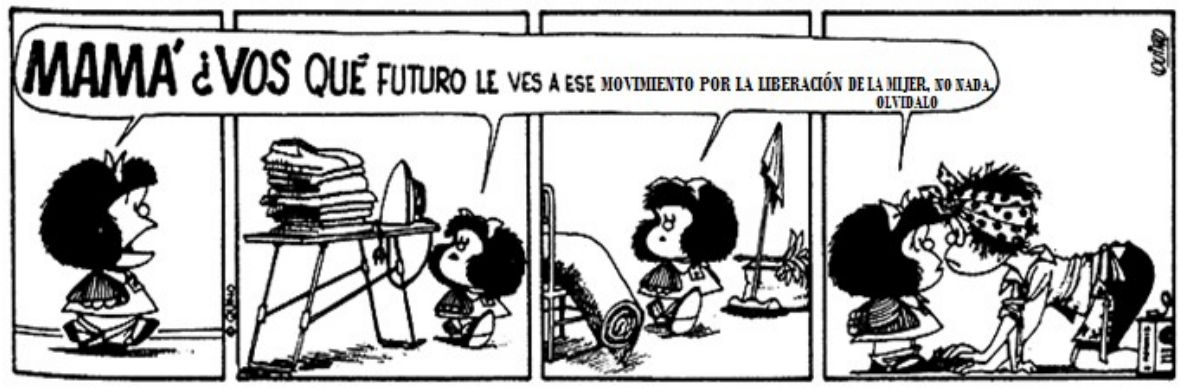

Figura 1 - Tirinha da Mafalda

Fonte: https://myhero.com/Mafalda_lyon_france_06_ul. Acesso em: 14 maio 2018.

Em aula posterior, apresentamos a reportagem da revista Veja de 18 de abril de 2016, de autoria de Juliana Linhares, intitulada "Marcela Temer: bela, recatada e "do lar", que foi matéria de muito debate à época de sua publicação, sobretudo pela acusação de que reforçava os estereótipos culturais reservados ao gênero feminino. Propusemos uma discussão sobre a política de "poder sobre o corpo feminino" (Del Re, 2009, p. 20), que tem sido pauta da agenda feminista em seus mais diversos movimentos e vertentes, e a necessidade do olhar do outro na constituição cultural do feminino, destacada por Bourdieu (2014, p. 97), ao afirmar que as mulheres "estão continuamente orientadas em sua prática pela avaliação antecipada do apreço que sua aparência corporal e sua maneira de portar o corpo e exibi-lo poderão receber".

Os demais encontros do projeto foram realizados no laboratório de informática do IFMS, que é a instituição de ensino básico mais bem equipada da cidade em termos de aparatos tecnológicos. Atualmente, o local conta com seis laboratórios de informática, que têm permitido o desenvolvimento de atividades que envolvem linguagens diversas e o acesso à internet. Isso nos oportunizou a criação de um grupo na rede social Facebook, no qual inserimos os estudantes e pelo qual propusemos duas atividades: a publicação de um comentário sobre a letra e o videoclipe da música "Triste, louca ou má", do grupo Francisco, el Hombre (2016); e a produção de memes que representassem seus posicionamen-

3 Tradução: "Mamãe! Como você vê esse movimento pela libertação da mulher? Não, nada. Esqueça”. 
tos a respeito das questões que haviam sido debatidas em sala de aula acerca da construção social do gênero.

No que tange ao videoclipe, usamos o seguinte comando de produção: "Ouça a canção e veja o vídeo. Feito isso, comente sobre os elementos visuais utilizados no vídeo que colaboram para a produção de sentido (relacionar letra e vídeo)”. A escolha do videoclipe foi motivada por sua intertextualização com a obra $O$ segundo sexo, da conhecida teórica feminista Simone de Beauvoir, bem como por ser um texto que mobiliza múltiplas semioses. Embora os comentários gerados não sejam objeto de análise neste trabalho, consideramos relevante notar que eles foram produzidos de forma individual, ou seja, sem interação entre os colegas, como é de costume na rede social utilizada. Acreditamos que isso possa estar relacionado ao fato de se tratar de contexto escolar e avaliativo. Como ilustram alguns exemplos reproduzidos na sequência (Figura 2), os alunos apenas curtiram a publicação de outros colegas, mas não as comentaram:

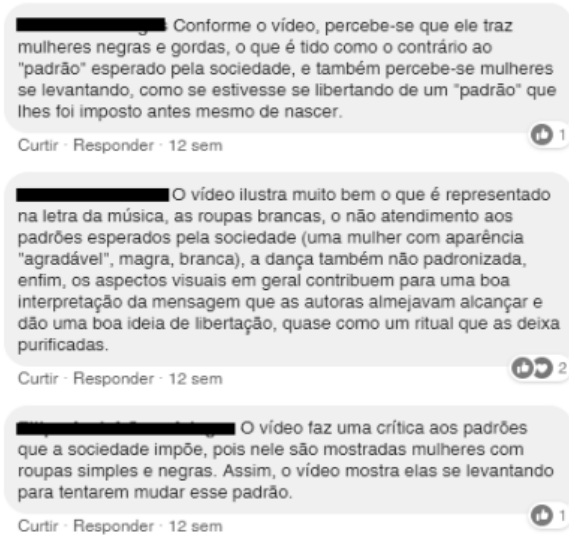

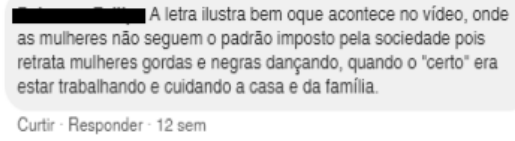

Curtir- Responder - 12 sem

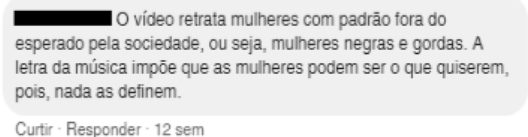

Curtir - Responder - 12 sem

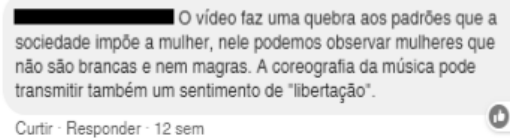

Figura 2 - Comentários postados no Facebook por estudantes do Instituto Federal de Educação, Ciência e Tecnologia de Mato Grosso do Sul sobre o videoclipe.

Quanto à atividade de produção dos memes, sugerimos às turmas que se dividissem em grupos de três a cinco integrantes. Posteriormente, pedimos que utilizassem o site https://www.gerarmemes.com.br/, ou qualquer outro que conhecessem e/ou com o qual tivessem afinidade, com o objetivo de produzir memes que representassem alguma(s) das questões de gênero debatidas nas aulas. Cada grupo tinha de criar no mínimo três memes. Finalizadas as produções, estas deveriam ser publicadas na página do Facebook com os nomes das pessoas que integravam o grupo ${ }^{4}$, conforme Figura 3.

Dada a perspectiva interpretativista deste estudo, entre os 43 memes produzidos, elegemos, por uma questão de espaço, dois para análise: um do grupo

4 Por questões éticas, optamos por não utilizar os nomes das alunas e dos alunos participantes da pesquisa. Como os memes foram produzidos em grupos, referimo-nos aos produtores/participantes como alunas/alunos. 
Info 5

11 de junho de $2018 \cdot$

Alunas:

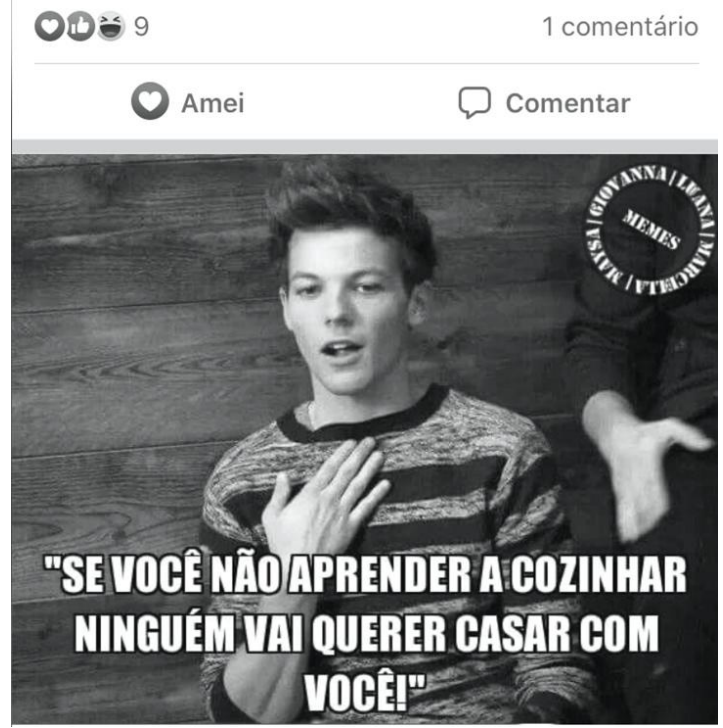

Figura 3 - Meme e identificação do grupo.

Fonte: arquivo pessoal dos autores, 2018.

Info (composto de quatro alunas) e um do grupo Edif (composto de dois alunos e duas alunas). A escolha dos exemplos deu-se por sua representatividade quanto às significações sobre o feminismo apresentadas no conjunto das produções e por revelarem algumas das mudanças relativas a tais construções antes e depois do projeto de ensino aqui brevemente situado. Cabe ressaltar que as análises refletem a crítica dos professores-pesquisadores sobre a crítica dos alunos via memes. Tais análises também estão baseadas nos questionários aplicados e nas impressões, anotações e observações de campo, em consonância com estudos de cunho etnográfico.

\section{AS CONSTRUÇÕES DO FEMININO NOS MEMES: ANÁLISES E DISCUSSÃO}

Em todos os memes produzidos, observamos processos de (res)significação do feminino pautados nos temas e na agenda das teorias contemporâneas de gênero, tais como igualdade de direitos, políticas contra a violência, intersecção entre gênero, sexualidade e raça, entre outros, que foram debatidos em sala de aula. No caso dos memes selecionados para análise, a exemplos de muitos outros que constituíram o corpus da pesquisa, os significados do feminino são construídos via questionamento da norma hegemônica do gênero, seus desdobramentos para a política de vigilância sobre o corpo feminino e o comportamento das mulheres sobretudo. É o que ilustra o exemplo da Figura 4, produzido pelo grupo de alunas do curso de Informática. 


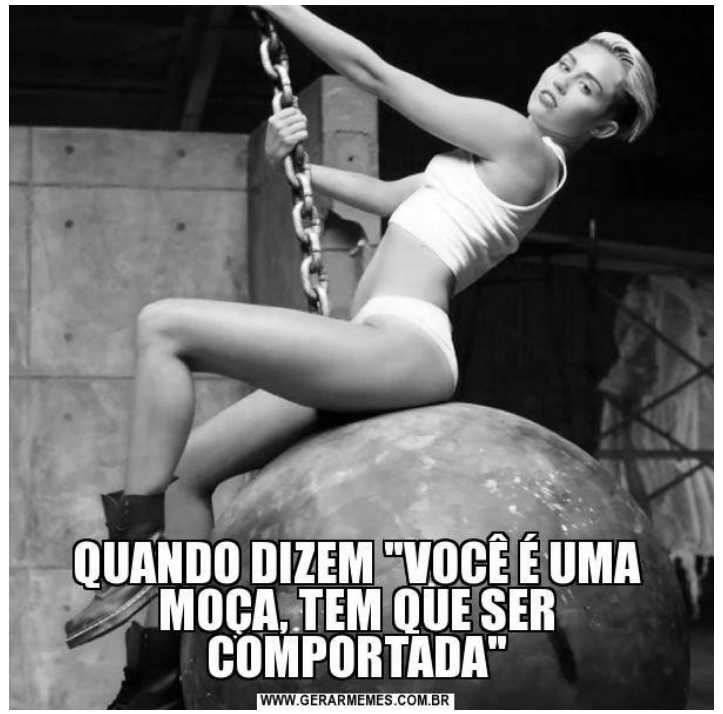

Figura 4 - Meme Miley Cyrus, produzido pelo Grupo Info Fonte: arquivo pessoal dos autores, 2018.

Nesse exemplo, a imagem da famosa cantora e atriz norte-americana Miley Cyrus, vestida de branco ${ }^{5}$ e agarrada a uma bola de demolição, é apresentada em segundo plano, ao que se sobrepõe a escrita "Quando dizem 'você é uma moça, tem que ser comportada". Em conjunto e por contraste, a imagem e os escritos remetem aos comportamentos relacionados tradicionalmente ao feminino e apreensíveis da reportagem "Bela, recatada e 'do lar", discutida com os alunos durante o projeto de ensino desta pesquisa. São os escritos que orientam primeiramente essa compreensão, por estarem em primeiro plano e por focalizarem a ideia de que a mulher teria de ser comportada, mas é somente pela junção entre a imagem e a escrita selecionadas para a produção do meme que esta última se revela em seu caráter irônico. Em contraposição à pressuposta mulher recatada, a imagem da cantora faz alusão à mulher ousada e questiona a vigilância moral do comportamento feminino, ressignificando o estereótipo de mulher recatada, ainda muito presente na contemporaneidade, como mostrou a citada reportagem.

E interessante notar que Miley foi, por alguns anos, a protagonista da série infantil Hannah Montana, produzida pelo Disney Channel, e teve uma imagem consagrada com esse público. Contudo, em seus trabalhos posteriores, especificamente do álbum "Bangerz", lançado em 2013, em diante, a cantora passou a surgir numa versão mais ousada e adulta, distanciando sua imagem do universo pueril e, concomitantemente, situando-a em um cenário pop mais jovem. Hoje em dia, bastante popular

5 Embora as imagens estejam apresentadas em tonalidades de cinza, faremos menção às cores originais durante as análises sempre que elas forem significativas para a compreensão das questões focalizadas. 
entre este último público, a cantora mostra-se bastante engajada em pautas feministas. Com frequência, expõe em seu perfil no Instagram mensagens sobre empoderamento feminino e demarca a sua resistência a discursos hegemônicos de gênero.

A síntese é importante para compreendermos a possível motivação das alunas que produziram esse meme: quatro adolescentes que acompanharam todo o processo de transição da artista, conforme identificamos em conversa informal com o grupo e registrado em diário de campo. A figura utilizada é um recorte de cena do videoclipe de "Wrecking ball", no qual Miley aparece primeiramente nua e na sequência com roupas curtas. Em entrevista concedida a Elvis Duran and the Morning Show (MILEY CYRUS AND MARK RONSON...,2018), ela revelou que sua nudez no videoclipe é uma metáfora de como ela se sente vulnerável.

A vulnerabilidade mencionada pela própria cantora pode ser inferida no meme pelo contraste entre a ideia de leveza (pouca roupa e de cor branca, posição desprendida da personagem jogando o corpo para trás) e a representação da força/rudez (bola de demolição, botas de trabalho pesado, contraste do branco com as cores cinza e preta, expressão séria e olhar direcionado para o leitor/observador). Trata-se, portanto, de uma construção do feminino que não se mantém apenas na unilateralidade dos estereótipos da mulher "bela, recatada e 'do lar", mas que ao feminino integra a força, a ousadia e a projeção de poder tradicionalmente atribuídas ao masculino. É a este último campo semântico, ainda, que o cabelo curto de Miley faz referência, em conjunto com os demais atributos de força culturalmente associados ao masculino e contrários ao ideal de comportamento apresentado de maneira irônica por meio da frase escrita.

A propósito do construto social de poder, faz-se pertinente notar também que o ângulo vertical apresenta a imagem capturada de baixo para cima, sugerindo, segundo Kress e Van Leeuwen (2006), que o participante representado detém o poder. Conforme Riot-Sarcey (2009), o poder tem sido desde sempre o centro das lutas e crises humanas, circunscrevendo-se, nas relações de gênero, na figura masculina e na exclusão das mulheres do "poder como potência", pela sujeição aos seus maridos embutida na cultura do patriarcado. A "mulher-livre", por sua vez, teria sido relacionada desde sempre à mulher pública, escandalosa e, portanto, subjugada. Para a autora, ao combater "a favor da igualdade, o feminismo é para as mulheres o meio de chegar tanto ao poder da palavra quanto ao poder da ação" (Riot-Sarcey, 2009, p. 188).

Os significados do feminino construídos pelo grupo de alunas por meio das semioses possibilitadas pelo meme superam, portanto, alguns dos construtos e das expectativas sociais e hegemônicas ligados ao gênero feminino. Essa superação é corroborada, a nosso ver, na sugestão de movimento implicada na imagem da bola de demolição, que alude à destruição e, simultaneamente, à reconstrução. Nesse sentido, tais significados são semelhantes aos que algumas alunas desse mesmo grupo compreendiam sobre gênero antes da proposta de intervenção. É o que observamos na resposta de uma delas ao ser perguntada sobre o que compreendia por feminismo: "É um tipo de movimento popular entre mulheres, com o objetivo de igualar quem manda 'mais', deixar tudo em um certo equilibrio entre homens e mulheres". Outra

6 Transcrevemos as respostas dos/das estudantes exatamente como foram apresentadas no preenchimento do questionário ou faladas e anotadas em diário de campo. 
aluna do grupo, antes da intervenção, também parecia significar o feminino por meio de ideias parecidas com as que podem ser inferidas do meme. Quando questionada sobre o que entendia por machismo, respondeu que seria "o ato que alguns homens cometem achando que são 'superiores' as mulheres de todas as formas. Exemplo: O homem trabalha fora de casa enquanto a mulher só tem que ficar cuidando da casa e dos filhos. $E$ como se a mulher não tivesse o direito de ter 'voz".

Por outro lado, e a título de exemplo, uma das alunas do grupo parecia ter uma compreensão bem diferente sobre o tema em comparação ao que se apresentou pelo meme. Ao ser questionada sobre o que entendia por feminismo, afirmou compreender o movimento como uma "doutrina de igualidade [sic] extrema da figura feminina em relação ao homem”. Além da conotação negativa apreensível do uso do léxico extrema, a aluna afirmou não acreditar na existência de discriminação de gênero nem de machismo em nossa sociedade. Embora não possamos presumir que as ideias do meme analisado representem, de fato, os significados do feminino para todas as alunas do grupo, consideramos ser notável a participação desta última na produção de significados tão distintos quanto aos que apontou antes de seu envolvimento nas atividades das aulas.

Movimento semelhante pode ser observado na Figura 5. Nela, duas frases são postas em primeiro plano (uma na parte superior e outra na parte inferior da figura) em função de uma imagem ao fundo: a da garotinha americana Zoe Roth, observando um teste de controle de chamas do corpo de bombeiros. Segundo informações que circularam na internet, seu pai teria tirado a foto e publicado-a, posteriormente, utilizando a legenda Firestarter, de modo a sugerir que a garota tivesse iniciado as chamas (Donovan, 2018). Essa imagem tornou-se uma das mais populares da internet no ano de 2004 e ficou mundialmente conhecida como disaster girl (menina desastre), tendo sido replicada, desde então, em milhares de memes na internet, a propósito dos mais variados temas.

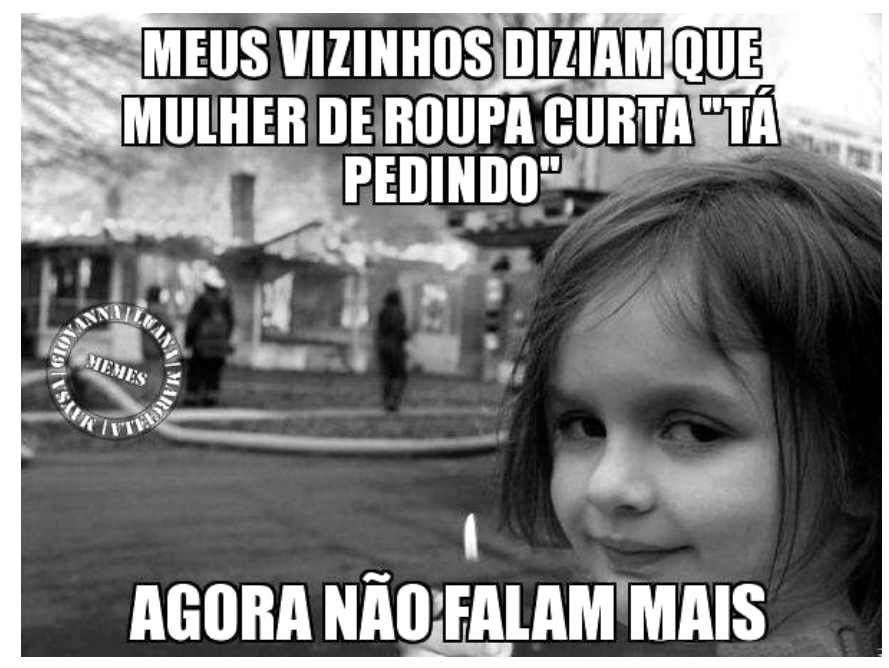

Figura 5 - Meme Zoe Roth, produzido pelo Grupo Edif.

Fonte: arquivo pessoal dos autores, 2018. 
Os escritos na parte superior ("Meus vizinhos diziam que mulher de roupa curta 'tá pedindo") selecionam, entre os temas de gênero trabalhados na sala de aula, a questão da vigilância sobre o corpo feminino no sistema patriarcal. Em última instância, remetem à culpabilização da vítima na "cultura do estupro", ou seja, ao "conjunto de violências simbólicas que viabilizam a legitimação, a tolerância e o estímulo à violação sexual” (Sousa,2017). Posicionada na parte inferior da figura, a frase "agora não falam mais" complementa não apenas os escritos da parte superior, mas também a imagem ao fundo. O sorriso sarcástico e o olhar direcionado para o observador de Zoe, em segundo plano, somam-se à imagem de uma casa em chamas no terceiro plano e introduzem o tom irônico e debochado do meme: uma crítica ao controle sobre o comprimento de roupas usadas por mulheres, culturalmente ligado a uma das formas de insinuar-se para os homens e, de modo estereotipado, ligado à relação ideologicamente construída entre roupa e moral.

Conforme discutimos em sala de aula, a ideia de vigilância sobre o corpo feminino tem sido um dos tópicos da agenda feminista desde o seu surgimento, no contexto do movimento sufragista, inaugurado na França nos anos de 1970 (Del Re, 2009, p. 21). O questionamento sobre quem possui o direito sobre o corpo feminino (o Estado, as corporações médicas, o patriarca da família, as autoridades religiosas ou a própria mulher) atravessa as discussões feministas sobre maternidade, protestos de rua ou aborto desde então e tem ressurgido com força nos discursos de direita dos últimos anos, que, de modo geral, têm se recusado a "ver as mulheres como sujeitos autônomos" (Del Re, 2009, p. 24). Ao ironizar a questão pela escolha da imagem e dos escritos apresentados no meme, o grupo faz referência à relação entre o controle do corpo feminino e a construção social de moral que constitui as relações de gênero. De acordo com Cornell (2018), é a ideia de moralidade que está por trás de toda tentativa "de explicar teoricamente como é possível determinar um sistema que governe absolutamente a "maneira certa de se comportar"'(Cornell, 2018, p. 128).

No meme, a atenção do leitor é direcionada para o rosto da menina, que se mantém nítido na figura, em contraste com a imagem em terceiro plano, que aparece desfocada. Ao apresentar uma personagem infantil feminina e chamar a atenção para ela, o meme traz também à tona uma crítica que se costuma apresentar: a "docilidade e resignação são as características esperadas das menininhas" (Lakoff, 2010, p. 21). Subvertendo essa norma ao apresentar uma garota que, num ato de inconformidade, ateou fogo na casa daqueles que a incomodavam, as ideias do meme alinham-se a essa crítica, de forma a questioná-la. A comicidade é então construída, no meme, sobretudo pelo foco em Zoe, uma figura feminina e infantil, segurando uma vela (símbolo tradicionalmente ligado ao mundo espiritual e, por vezes, ao universo sombrio) com o semblante de satisfação após ter solucionado um problema que a incomodava: a vigilância e o julgamento moral dos vizinhos sobre o tamanho de suas roupas.

Cabe ressalvar que, durante a realização do projeto de ensino, houve preocupação por parte do professor com o aspecto de violência, também passível de ser apreendido pelo meme. Ao conversar a respeito com o grupo, em sala de aula, o professor mencionou sua preocupação estabelecendo relação com o ditado popular 
"olho por olho, dente por dente" e questionando os alunos e as alunas quanto ao risco de responder à violência com violência. Os estudantes, no entanto, disseram que a imagem, em suas múltiplas ressignificações na internet, é comumente associada com algum problema que, grosso modo, pode ser "resolvido de forma rápida e simples", não necessariamente pela violência. Conforme mencionaram os alunos, a ideia do meme consiste em expor alguma situação incômoda e sugerir uma forma imediata de resolvê-la, de maneira cômica e irônica. Ainda que possa soar violenta, portanto, essa produção multimodal demonstra que os estudantes têm contato com as redes sociais e, sobretudo, que compreendem a dinâmica atribuída à imagem, uma vez que seguem o modelo de uso/réplica característico dos memes. Trata-se, então, a nosso ver, de uma possibilidade de abertura para o trabalho com o tema da violência em outros projetos de (multi)letramentos.

De todo modo, a subversão da norma de gênero que responde pelos julgamentos relacionados aos comportamentos sociais designados para o feminino (Butler, 2017), no meme, sugere um alinhamento desses alunos com alguns de seus posicionamentos sobre a questão anterior ao projeto de ensino. É o caso de uma das alunas do grupo, que, em questionário que precedeu as aulas, afirmou ser o machismo uma

tentativa de bloquear os direitos das mulheres. Temos algumas frases para dar exemplo, como: "Lugar de mulher é na cozinha", no trânsito usar a expressão "Tinha que ser mulher mesmo", quando andamos sozinhas com um short acima da metade da coxa dizem "Olha lá, tá pedindo". Em situações do dia a dia vemos o machismo até no direito de ter relaçôes (sexuais ou não) com as pessoas, por exemplo, se uma menina fica com vários rapazes, ela fica com uma "fama" ruim ("vagabunda, piranha, biscate" $e$ várias outras palavras chulas), mas se um menino fica com várias meninas, fica com uma "fama" boa, de "garanhão", "bonitão", "conquistador".

Segundo essa mesma aluna, o feminismo seria o "ato de lutar pelos direitos das mulheres, alguns exemplos já conquistados são: o voto, ingressar na faculdade, trabalhar fora. Hoje lutamos pelo fim da violência doméstica, pelo direito de andar desacompanhada e em segurança e por vários outros motivos". Interessante notar, ainda, que um dos alunos do grupo mencionou ter tido em outro ano uma aula de sociologia e uma palestra nas quais teria sido trabalhado o tema das relações de gênero. Segundo ele, nesses momentos anteriores ele aprendeu muitas coisas sobre os direitos das mulheres e também que "nós devemos ser o que queremos, e se somos feliz porque ter que ouvir a opinião dos outros".

Esse dado, aliado a algumas respostas de alunos e alunas sobre discussões de gênero que acompanharam na televisão ou na internet, leva-nos a ressalvar a impossibilidade de inferir que toda a crítica a respeito da questão apresentada no

7 Resposta de uma aluna do curso técnico em informática registrada no Google Formulários. A planilha gerada automaticamente pela ferramenta com as respostas e os dados dos/das participantes (nome, turma e respostas) integram o acervo pessoal dos pesquisadores. 
meme é fruto do projeto de ensino desta pesquisa. Como mostramos brevemente, nas análises, muitos dos alunos já tinham conhecimento acerca do tema e construíam significados sobre o feminino de forma semelhante ao que foi exibido por meio dos memes.

No entanto, entre os casos de mudança que nos chamaram a atenção após a realização do projeto de ensino e nos permitiram responder à nossa segunda questão de pesquisa, destacamos um que revelou alterações que consideramos significativas quanto à construção do feminino. Trata-se de uma estudante do grupo que produziu o meme sob análise e que, em conversa informal com o professor, ao final da intervenção, mencionou ter sido abusada por um líder religioso e ocultado a violência a pedido da família, para preservar a imagem do abusador. Segundo relatou a aluna, antes das aulas ela se sentia culpada pelo ocorrido, mas "agora eu entendo que é uma coisa muito maior do que eu".

\section{CONSIDERAÇÕES FINAIS}

Este artigo apresentou algumas das ressignificações sobre o feminino construídas por alunas e alunos de dois cursos técnicos do IFMS, campus Aquidauana, antes e depois da realização de um projeto de ensino sobre questões de gênero e violências físicas e morais relacionadas às mulheres. $O$ projeto ocorreu entre os meses de maio e junho do ano de 2018, contou com a participação de 58 estudantes do $5^{\circ}$ semestre e foi o locus de geração dos registros desta pesquisa. Ao constatar os altos índices de violência de gênero no estado de Mato Grosso do Sul, o projeto foi elaborado com o propósito de se somar a outras ações educacionais e de se concatenar com a formação cidadã crítica e empática ao sofrimento humano ligados às relações de gênero.

Entre os registros gerados e coletados por intermédio do projeto, selecionamos para este trabalho os memes produzidos por dois grupos de estudantes em página da rede social Facebook. Em perspectiva transdisciplinar cara ao campo aplicado dos estudos da linguagem, baseamo-nos em teorias sobre a pedagogia dos multiletramentos, sobre o meme e sobre gênero e feminismo, com o intuito de melhor compreender as seguintes questões: como se dá o processo de (res) significação do feminino nos memes produzidos pelos alunos? Os memes revelam alguma mudança em relação aos significados do feminino, em comparação com a compreensão desses alunos antes da aplicação do projeto de ensino?

Conforme buscamos mostrar pelas análises dos dois exemplos recortados para o trabalho, alunos e alunas participantes da pesquisa construíram, por meio da associação entre linguagem escrita e imagens, significados sobre o feminino pautados na subversão da norma hegemônica de gênero fixada pela cultura moderna ocidental. Fizeram-no mediante a produção de memes, apropriando-se de significados em circulação nas redes sociais contemporâneas e retextualizando questões por meio de crítica social - uma das habilidades implicadas à produção de memes e esperadas quando se trabalha com a pedagogia dos multiletramentos.

Além disso, observamos que os significados do feminino construídos se diferenciavam, em alguns casos, dos que os alunos demonstraram antes da proposta 
de intervenção. Embora, como ressalvamos, não possamos (nem pretendamos) inferir que tal proposta tenha efetuado grandes mudanças, em nível quantitativo, às significações dos estudantes sobre as questões trabalhadas, foi em cada um dos pequenos exemplos que nos saltavam aos olhos antes, ao longo e depois da realização deste estudo que constatamos a importância do trabalho educacional crítico, engajado e antenado às relações de poder geradoras de sofrimento entre os alunos, dentro e fora das instituições de ensino.

A propósito disso, mobilizamos as vozes de duas estudantes participantes da pesquisa para finalizar nossas considerações e salientar a ideia de que " $a$ identidade de gênero é algo que não é muito discutido, muitas pessoas sofrem em silêncio, sem serem quem realmente são, sem se aceitarem, por medo do que os amigos ou familia irão pensar, e quando isso é tratado, algumas duvidas podem ser sanadas", assim como para chamar a atenção para o fato de que, se instituições educacionais

realizassem ações para esclarecer e conscientizar a seus alunos teríamos a diminuição em casos de ódio e preconceito, bem como novas formas para combater esse males que mudam e causam tantos impactos negativos na vida de quem os sofre. Deste modo utilizaríamos a melhor ferramenta possivel para o combate, a educação.

\section{REFERÊNCIAS}

BARTON, D.; LEE, C. Linguagem online: textos e práticas digitais. Tradução: Milton Camargo Mota. São Paulo: Parábola, 2015.

BIONDO, F. P. “Liberte-se dos rótulos”: questões de gênero e sexualidade em práticas de letramento em comunidades ativistas do Facebook. Revista Brasileira de Linguística Aplicada, v. 15, p. 209-236, 2015. Disponível em: https://doi.org/10.1590/1984639820155871. Acesso em: 23 ago. 2021.

BOURDIEU, P. A dominação masculina. Tradução: Maria Helena Kuhner. Rio de Janeiro: Best Bolso, 2014.

BRASIL. Secretaria Nacional de Políticas para as Mulheres. Balanço 2014 Ligue 180: Central de Atendimento à Mulher. Brasília: Secretaria Nacional de Políticas para as Mulheres, 2014. Disponível em: http://www.mulheres.ba.gov.br/arquivos/File/ Publicacoes/Balanco_Ligue180_2014.pdf. Acesso em: 11 maio 2018.

BUTLER, J. Corpos que pesam: sobre os limites discursivos do "sexo". In: LOURO, G. L. (org.). O corpo educado: pedagogia da sexualidade. 2. ed. Belo Horizonte: Autêntica, 2003. p. 151-172.

BUTLER, J. Problemas de gênero: feminismo e subversão da identidade. Tradução: Renato Aguiar. 13. ed. Rio de Janeiro: Civilização Brasileira, 2017.

BUTLER, J. Corpos em aliança e a política das ruas: notas para uma teoria performativa de assembleia. Rio de Janeiro: Civilização Brasileira, 2018. 
CORNELL, D. O que é feminismo ético? In: BENHABIB, S. et al. (org.). Debates feministas: um intercâmbio filosófico. Tradução: Fernanda Veríssimo. São Paulo: Editora da Unesp, 2018. p. 117-160.

DAWKINS, R. O gene egoísta. São Paulo: Companhia das Letras, 2017.

DEL RE, A. Aborto e contracepção. In: HIRATA, H. et al. (org.). Dicionário crítico do feminismo. São Paulo: Editora da Unesp, 2009. p. 21-22.

DONOVAN, F. Disaster girl meme explains what was really happening. Unilad, 12 out. 2018. Disponível em: https://www.unilad.co.uk/featured/disaster-girl-meme-explainsfire/. Acesso em: 5 nov. 2018.

FABRÍCIO, B. F. Linguística aplicada como espaço de desaprendizagem: redescrições em curso. In: MOITA LOPES, L. P. (org.). Por uma linguística aplicada indisciplinar. São Paulo: Parábola, 2006. p. 45-65.

FRANCISCO, EL HOMBRE. Triste, louca ou má. You Tube, 5 out. 2016. 4min29s. Disponível em: https://www.youtube.com/watch?v=1KmYTHgBNoE. Acesso em: 11 jun. 2018.

GOELLNER, S. V.A produção cultural do corpo. In: LOURO, G. et al. (org.). Corpo, gênero e sexualidade: um debate contemporâneo na educação. Petrópolis: Vozes, 2003. p. 30-42.

HOOKS, B. O feminismo é para todo mundo: políticas arrebatadoras. Tradução: Ana Luiza Libânio. 2. ed. Rio de Janeiro: Rosa dos Tempos, 2018.

INOCÊNCIO, L. May the memes be with you: uma análise das teorias dos memes digitais. In: SIMPÓSIO DE PESQUISADORES EM CIBERCULTURA, 9., 2016. Anais [...]. São Paulo: ABCiber, 2016. Disponível em: https://abciber.org.br/ anaiseletronicos/wp-content/uploads/2016/trabalhos/may_the_memes_be_with_you_ uma_analise_das_teorias_dos_memes_digitais_luana_ellen_de_sales_inocencio.pdf. Acesso em: 23 ago. 2021.

INSTITUTO FEDERAL DE MATO GROSSO DO SUL (IFMS). Projeto Pedagógico de Curso: Informática. Aquidauana: IFMS, 2017. Disponível em: http://www.ifms.edu.br/centrais-de-conteudo/documentos-institucionais/projetospedagogicos/projetos-pedagogicos-dos-cursos-tecnicos/projeto-pedagogico-do-cursotecnico-em-informatica-aquidauana.pdf. Acesso em: 14 fev. 2018.

KLEIMAN, A. B. O estatuto disciplinar da lingüística aplicada: o traçado de um percurso, um rumo para o debate. In: SIGNORINI, I.; CAVALCANTI, M. C. (org.). Lingüística aplicada e transdiciplinaridade: questões e perspectivas. Campinas: Mercado de Letras, 1998. p. 47-70.

KNOBEL, M.; LANKSHEAR, C. Online memes, affinities, and cultural production. In: KNOBEL, M.; LANKSHEAR, C. (org.). A new literacies sampler. Nova York: Peter Lang, 2006. p. 199-227.

KRESS, G.; VAN LEEUWEN, T. Reading images: the grammar of visual design. 2. ed. Londres e Nova York: Routledge, 2006.

LAKOFF, R.Linguagem e lugar da mulher.In: OSTERMANN,A.C.; FONTANA,B. (org.). Linguagem, gênero, sexualidade: clássicos traduzidos. São Paulo: Parábola, 2010. p. 13-30. 
LEONE, P. N. (Pitty). Desconstruindo Amélia. Disponível em: https://www.letras. mus.br/pitty/1524312/. Acesso em: 13 maio 2018.

LINHARES, J. Marcela Temer: bela, recatada e "do lar". Veja [online], 18 abr. 2016. Disponível em: https://veja.abril.com.br/brasil/marcela-temer-bela-recatada-e-do-lar/. Acesso em: 10 maio 2018.

LOURO, G. L. Pedagogias da sexualidade. In: LOURO, G. L. (org.). O corpo educado: pedagogias da sexualidade. 2. ed. Belo Horizonte: Autêntica, 2003. p. 7-34.

LOURO, G. L. Gênero e sexualidade: pedagogias contemporâneas. Pro-posições, Campinas,v.19, n.2,p.17-23,2008.https://doi.org/10.1590/S0103-73072008000200003

MATOS, M. Teorias de gênero ou teorias e gênero? Se e como os estudos de gênero e feministas se transformaram em um campo novo para as ciências. Estudos Feministas, Florianópolis, v. 16, n. 2, p. 333-357, 2008. https://doi.org/10.1590/S0104026X2008000200003

MILEY CYRUS AND MARK RONSON ON "NOTHING BREAKS LIKE A HEART”. Elvis Duran Show. YouTube, 10 dez. 2018. 21min48s. Disponível em: https://www.youtube.com/watch?v=FI4L6vSE5hU. Acesso em: 8 maio 2019.

MILNER, R. M. The world made meme: discourse and identity in participatory media. Tese (Doutorado em Filosofia) - Universidade do Kansas, Kansas, 2012. Disponível em: https://kuscholarworks.ku.edu/handle/1808/10256. Acesso em: 1º nov. 2018.

MISKOLCI, R. Teoria queer: um aprendizado pela diferença. 3. ed. Belo Horizonte: Autêntica / UFOP, 2017. (Cadernos da Diversidade).

MOITA LOPES, L. P. Identidades fragmentadas: a construção discursiva de raça, gênero e sexualidade em sala de aula. Campinas: Mercado de Letras, 2002.

NARVAZ, M. G.; KOLLER, S. H. Metodologias feministas e estudos de gênero: articulando pesquisa, clínica e política. Psicologia em Estudo, v. 11, n. 3, p. 647-654, 2006. https://doi.org/10.1590/S1413-73722006000300021

NELSON, C.D. A teoria queer em linguística aplicada: enigmas sobre "sair do armário" em salas de aula globalizadas. In: MOITA LOPES, L. P. (org.). Por uma linguística aplicada indisciplinar. São Paulo: Parábola, 2006. p. 215-235.

NEW LONDON GROUP (NLG). A pedagogy of multiliteracies: designing social futures. In: COPE, B.; KALANTZIS, M. (org.). Multiliteracies: literacy learning and the design of social futures. Nova York: Routledge, 2006. p. 9-37.

PINTO, R. P. A. O ponto de vista feminista. In: PINTO, R. et al. (org.). Feminismo, pluralismo e democracia. São Paulo: LTr, 2018. p. 11-15.

RAJAGOPALAN, K. Por uma linguística crítica: linguagem, identidade e representação. São Paulo: Parábola, 2003.

RECUERO, R. Redes sociais na internet. 2. ed. Porto Alegre: Sulina, 2018.

RIOT-SARCEY, M. Poder(es). In: HIRATA, H. et al. (org.). Dicionário crítico do feminismo. São Paulo: Editora da Unesp, 2009. p. 183-184.

ROJO, R. Letramentos múltiplos, escola e inclusão social. São Paulo: Parábola, 2009. 
SABAT, R. Gênero e sexualidade para consumo.In: LOURO, G. et al. (org.).Corpo,gênero e sexualidade: um debate contemporâneo na educação.Petrópolis:Vozes, 2003.p.149-159. SAFFIOTI, H. I. B. O poder do macho. São Paulo: Moderna, 1987.

SIGNORINI, I. Letramentos multi-hipermidiáticos e formação de professores de língua. In: SIGNORINI, I.; FIAD, R. S. (org.). Ensino de língua: das reformas, das inquietações e dos desafios. Belo Horizonte: Editora da UFMG, 2012. p. 282-303.

SOUSA, R. F. Cultura do estupro: prática e incitação à violência sexual contra mulheres. Estudos Feministas, Florianópolis, v. 25, n. 1, p. 9-29, 2017. https://doi. org/10.1590/1806-9584.2017v25n1p9

TEJÓN, J. S. L. (Quino). Tirinha Mafalda. Disponível em: https://myhero.com/ Mafalda_lyon_france_06_ul. Acesso em: 14 maio 2018.

\section{SOBRE OS AUTORES}

Fabiana Poças Biondo Araújo é doutora em linguística aplicada pela Universidade Estadual de Campinas (UNICAMP). Professora da Universidade Federal de Mato Grosso do Sul (UFMS).

E-mail: fabibiondo@gmail.com

Juvenal Brito Cezarino Júnior é doutorando em linguística aplicada pela Universidade Estadual de Campinas (UNICAMP). Professor do Instituto Federal de Educação, Ciência e Tecnologia de Mato Grosso do Sul(IFMS), campus Aquidauana. E-mail: juvenal.cezarino@ifms.edu.br

Conflitos de interesse: Os autores declaram que não possuem nenhum interesse comercial ou associativo que represente conflito de interesses em relação ao manuscrito.

Financiamento: $\mathrm{O}$ estudo não recebeu financiamento.

Contribuições dos autores: Administração do Projeto, Curadoria de Dados, Escrita - Primeira Redação,Investigação: Cezarino,J.B. Análise Formal, Conceituação, Escrita - Revisão e Edição, Metodologia, Supervisão, Validação e Visualização: Cezarino, J.B.; Biondo, F.P.

Recebido em 12 de maio de 2019

Aprovado em 2 de fevereiro 2021 